\title{
Communication
}

[Comunicação]

\section{Uterine leiomyoma in chimpanzee (Pan troglodytes)}

[Leiomioma uterino em chimpanzé (Pan troglodytes)]

\author{
A.E. Silva ${ }^{1}$, N.M. Ocarino ${ }^{1}$, G.D. Cassali ${ }^{2}$, E.F. Nascimento ${ }^{1}$, M.A. Coradini $^{1}$, R. Serakides ${ }^{1 *}$ \\ ${ }^{1}$ Escola de Veterinária - UFMG \\ Caixa Postal 567 \\ 30123-970 - Belo Horizonte, MG \\ ${ }^{2}$ Instituto de Ciências Biológicas - UFMG
}

Reports of tumors of the reproductive tract in female non-human primates are not frequent. In the literature some cases were observed in females, and they included a cervical leiomyoma, an uterine carcinoma (Mcclure and Guilloud, 1971), four uterine leiomyomas (Seibold and Wolf, 1973; Toft and Mac Kenzie, 1975) an endometrial adenocarcinoma in situ (Hertig and Mackey, 1973), a tumor of the endometrial stroma (Toft and Mac Kenzie, 1975) and a fibrothecoma (Graham and McClure, 1977) .Those neoplasms are of interest, because they allow for the comparative study between monkeys and humans in respect to their phylogenetic proximity (Toft and Mac Kenzie, 1975; Graham and McClure, 1977).

Uterine leiomyoma is a benign neoplasm of smooth muscle frequently found in women 35 years and older (Maruo et al., 2000), and in cows, cats and dogs (Meuten, 2002). The genesis of uterine leiomyoma involves somatic mutations and a complex interaction with trophic sex hormones and growth factors (Rein et al., 1995) However, the molecular mechanism of action of those hormones is not well elucidated (Maruo et al., 2000). Estrogen is considered the largest promoter of neoplastic growth, but researches demonstrated that progesterone also stimulates the mitotic activity myometrial cells ( $\mathrm{Vu}$ et al., 1998).

The function of hormonal receptors in hormonedependent neoplasms such as leiomyoma has been studied. It is believed that there is a relationship between the number of hormone receptors and the proliferative capacity of the neoplastic cells. With tumor progression and increasing malignancy there is a reduction in the number of the receptors and on the neoplastic cells hormonal dependence (Lippman, 1993).

This report describes the pathologic and immunohistochemical characteristics of a uterine leiomyoma in a 22-year-old, female chimpanzee (Pan troglodytes). The animal belonged to a circus and was referred a Veterinary Teaching Hospital. The animal had been receiving injectable contraceptives containing estrogen and progesterone, monthly, since puberty to prevent estrus. The animal presented with a history of anorexia, frequent vomiting and dehydration due to an iatrogenic gastritis caused by the indiscriminate use of an anti-inflammatory drugs in the post-operative treatment of a fractured right tibia and fibula. Upon admission the animal received fluid therapy with ringer lactate, ranitidine and metoclopramide. The animal was

Recebido em 22 de julho de 2004

Aceito em 5 de setembro de 2005

*Corresponding author (autor para correspondência)

E-mail: serakide@dedalus.lcc.ufmg.br 
unresponsive to treatment and died the following day.

At necropsy, hemorrhagic gastritis, ulcerative esophagitis and an intense congestion and edema of the lungs were presented. The uterus was enlarged with the lumen totally occluded by coalescent, whitish firm nodules that blended into the myometrium. The ovaries appeared normal with small follicles on their surface and the absence of corpora lutea.

Portions of the uterus involved with the nodules were fixed in buffered $10 \%$ formalin and routinely embedded in paraffin. Four-micrometer sections were stained with hematoxylin and eosin, Masson's trichrome and Gomori's trichrome. For the study of the immunohistochemical features of the nodules, the following antibodies were applied in appropriate dilutions: anti-vimentin ${ }^{1}$, smooth muscle anti-alpha actin ${ }^{2}$, anti-estrogen receptor ${ }^{3}$, anti-progesterone receptor ${ }^{4}$ and anti-MIB- $1^{5}$. The streptavidin-biotin-peroxidase complex and diaminobenzidin ${ }^{6}$ were used as the detection system. Sections were counterstained with Harris hematoxylin.

Histologically, the nodules were composed of well differentiated neoplastic leiomyocytes forming bundles coursing in several directions (Fig. 1). The neoplastic cells had an abundant eosinophilic cytoplasm with oval or elongated nuclei showing a dense nuclear chromatin pattern. Mitotic figures were rare. The neoplastic leiomyocytes presented a typical staining pattern with Gomori and Masson's trichromie showing neoplastic cell bundles surrounded by moderate amounts of well-vascularizated connective tissue.

By immunohistochemistry, the nuclei of the neoplastic cells and of the vascular endothelium showed a strong and diffuse labeling for estrogen receptor (Fig. 2). However, only in the nuclei of the neoplastic cells was there a strong and diffuse labeling for progesterone receptor (Fig. 3). The cytoplasm of the neoplastic cells strongly labeled for smooth muscle alpha actin (Fig. 4). Only some neoplastic cells were labeled for the cellular proliferation factor MIB-1. Strong reaction for vimentin was observed in the connective tissue.

The immunohistochemical features found in this neoplasm are similar to those descrited for uterine leiomyoma in women, where large numbers receptors for estrogen and progesterone have been observed (Brandon et al., 1995; Vu et al., 1998; Ichimura et al., 1998) and there is an inverse correlation between the density of these receptors and markers of the proliferative activity of the cells (Mittal and Demopoulos, 2001).Other reports have also demonstrated the occurrence of estrogen receptors in rat vascular endothelium associated with uterine lyomyomas (Andersson et al., 2001), similar to those observed in the current report. Estrogen is thought to induce angiogenesis by inducing the synthesis and expression of the vascular endothelial growth factor (VEGF), fibroblast growth factor (FGF) and of nitric oxide, a potent vasodilator ( $\mathrm{Li}$ et al., 2002; Rubanyi et al., 2002). Nitric oxide has been found in high concentrations in gynecological neoplasms of women and it shows an inverse correlation with the tumor's degree of differentiation (Thomsen et al., 1994). However, the precise effect of the estrogen on the endothelium of blood vessels of uterine leiomyoma is not known.

On the basis of anatomopathologic findings, the diagnosis of uterine leiomyoma was made. The similarity between the immunohistochemical features of the Chimpanze's leiomyoma and that of the women suggests similar pathobiology.

Keywords: chimpanzee, uterus, leiomyoma, immunohistochemical

\footnotetext{
${ }^{1}$ V9, Dako, Carpintería, CA, USA, 1:100.

${ }^{2}$ HHF35, Dako, Carpintería, CA, USA, 1:200.

${ }^{3}$ 1D5, Novocastra, United Kingdom, 1:100.

${ }^{4}$ 1A6, Novocastra, United Kingdom, 1:10.

${ }^{5}$ MIB-1, Immunotech, France, 1:50.

${ }^{6}$ Sigma Aldrich, St Louis, Missouri, USA.
} 


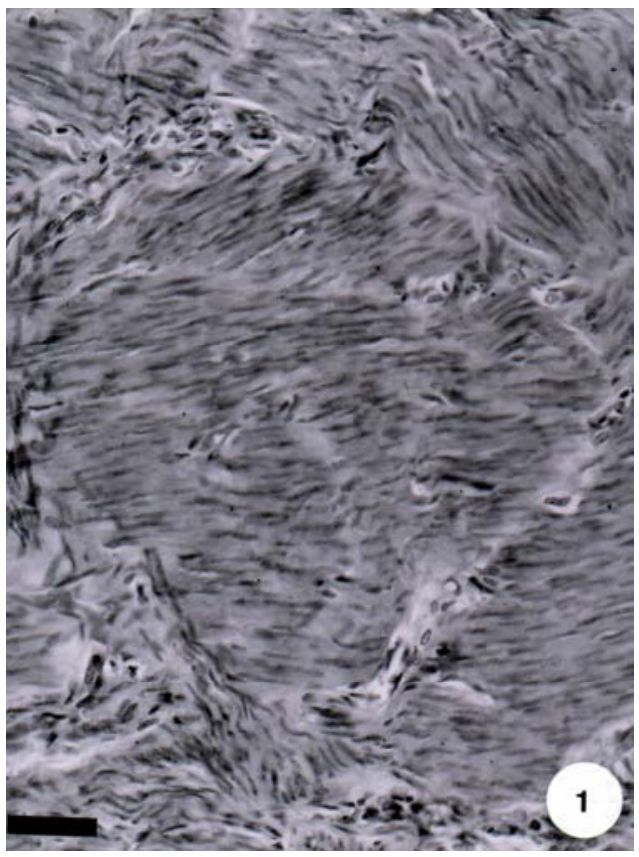

Figure 1. Uterine leiomyoma, chimpanzee. Well differentiated neoplastic leiomyocytes forming bundles coursing in several directions. HE. Bar = $46.7 \mu \mathrm{m}$

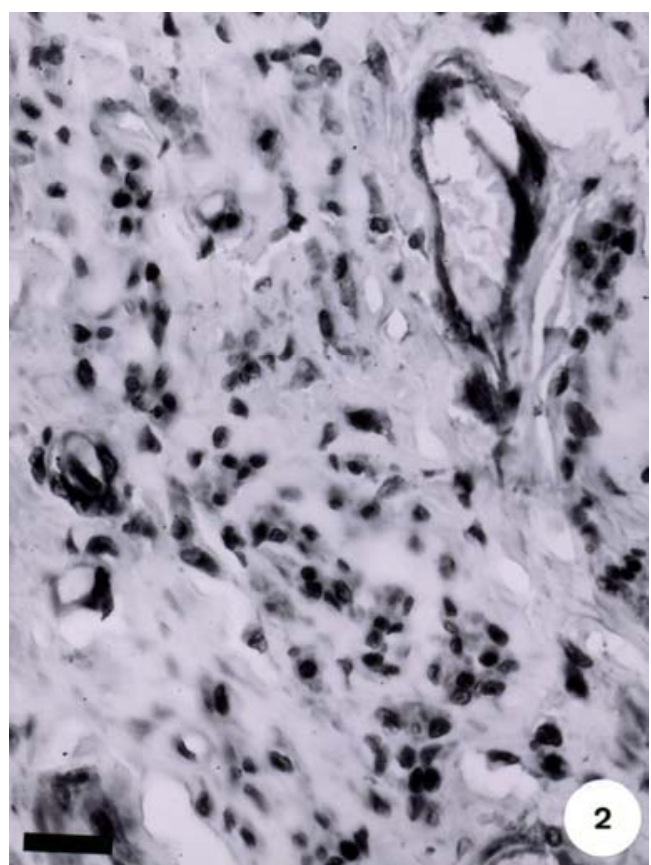

Figure 2. Uterine leiomyoma, chimpanzee. The nuclei of the neoplastic cells and of the vascular endothelium showed prominent immunoreactivity for estrogen receptors. Streptavidin-biotin-peroxidase method, Harris hematoxylin counterstain. $\mathrm{Bar}=15 \mu \mathrm{m}$

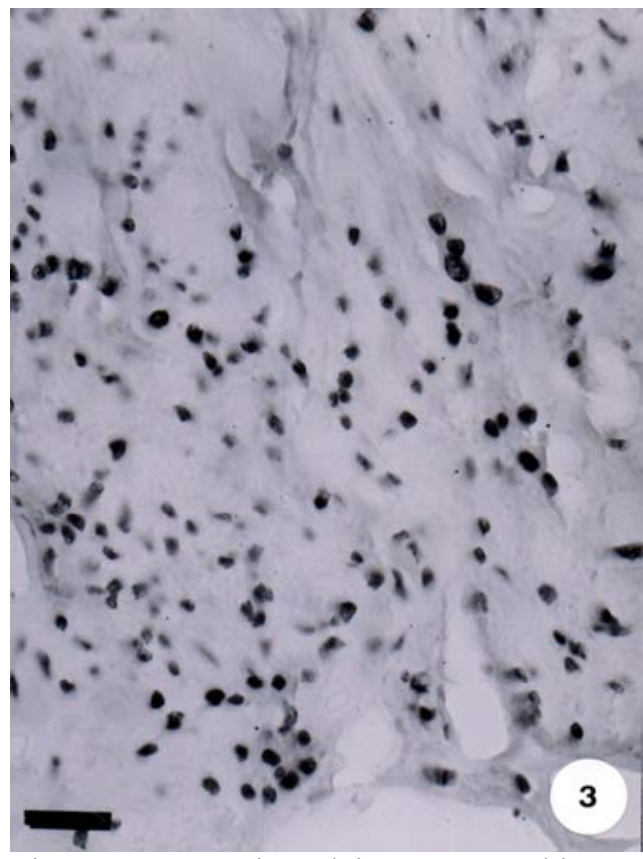

Figure 3. Uterine leiomyoma, chimpanzee. Strong and diffuse labeling for progesterone receptor in the nuclei of the neoplastic cells. Streptavidin-biotin-peroxidase method, Harris hematoxylin counterstain. Bar $=15 \mu \mathrm{m}$

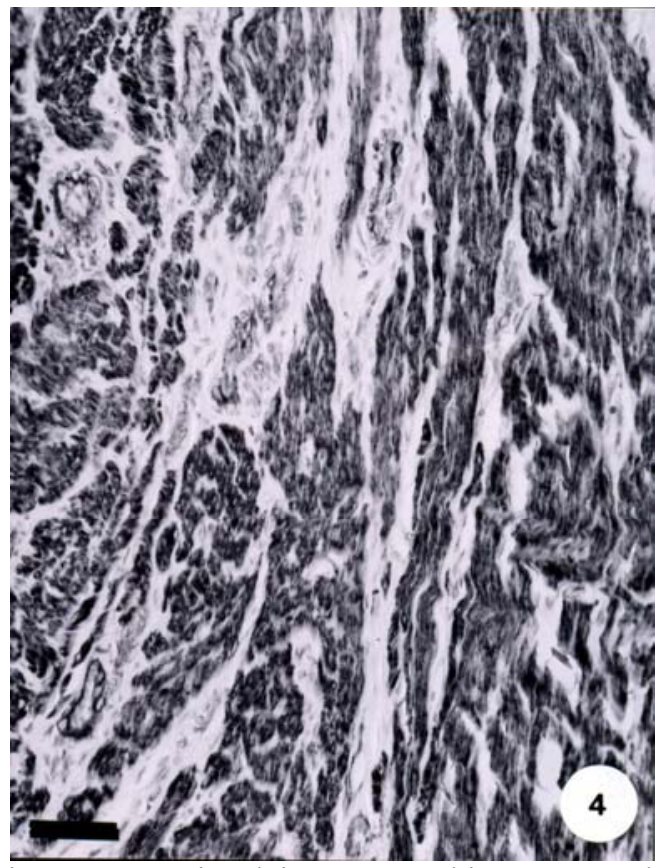

Figure 4. Uterine leiomyoma, chimpanzee. The cytoplasm of the neoplastic cells are strongly labeled for smooth muscle alpha actin. Streptavidin-biotin-peroxidase method, Harris hematoxylin counterstain. Bar $=46.7 \mu \mathrm{m}$ 


\section{RESUMO}

Uma chimpanzé de 22 anos de idade foi necropsiada com histórico clínico de anorexia, vômitos freqüentes e desidratação conseqüentes à gastrite iatrogênica. Macroscopicamente, o útero apresentavase aumentado de volume, com o lúmen totalmente ocluído por nódulos firmes, esbranquiçados $e$ coalescentes que se estendiam para o miométrio. Histologicamente, os nódulos eram constituídos por leiomiócitos bem diferenciados dispostos em várias direções e com coloração característica pelo tricrômio de Gomori e Masson. Pela imunoistoquímica, as células neoplásicas apresentavam marcação forte e difusa de receptores para progesterona e estrógeno, assim como de actina alfa de músculo liso. Algumas células neoplásicas e o estroma apresentavam marcação para vimentina e poucas células neoplásicas foram positivas para MIB-1. Com base nas características morfológicas e imunoistoquímicas foi firmado o diagnóstico de leiomioma uterino.

Palavras-chave: chimpanzé, útero, leiomioma, imunoistoquímica

\section{REFERENCES}

ANDERSSON, C.; LYDRUP, M.L.; FERNO, M. et al. Immunocytochemical demonstration of estrogen receptor beta in blood vessels of the female rat. $J$. Endocrinol., v.169, p.241-247, 2001.

BRANDON, D.D.; ERICKSON, T.E.; KEENAN, E.J. et al. Estrogen receptor gene expression in human uterine leiomyomata. J. Clin. Endocrinol. Metab., v.80, p.1876-1881, 1995.

GRAHAM, C.E.; McCLURE, H.M. Ovarian tumors and related lesions in aged chimpanzees. Vet. Pathol., v.14, p.380-386, 1977.

HERTIG, A.T.; MACKEY, J.J. Carcinoma in situ of the primate uterus: comparative observations on the cervix of the crab-eating monkey, macaca fascicularis, the endometrium of the chimpanzee, Pan troglodytes, and on similar lesion in the human patient. Gynecol. Oncol., v.1, p.165-183, 1973.

ICHIMURA, T.; KAWAMURA, N.; ITO, F. et al. Correlation between the growth of uterine leiomyoma and estrogen and progesterone receptors content in needle biopsy specimens. Fertil. Steril., v.70, p.967971, 1998.

LI, H.; WALLERATH, T.; FORSTERMANN, U. Physiological mechanisms regulating the expression of endothelial-type in the synthase. Nitric Oxide, v.7, p.132-147, 2002.

LIPPMAN, M.E. The development of biological therapies for breast cancer. Science, v.259, p.631-632, 1993.
MARUO, T.; MATSUO, H.; SAMOTO, T. et al. Effects of progesterone on uterine leiomyoma growth and apoptosis. Steroids, v.65, p.585-592, 2000.

McClURE, H.M.; GUILLOUD, N.B. Comparative pathology of the chimpanzee. In: The chimpanzee. Basel: Bourne, 1971. v.4, p.103-272

MEUTEN, D.J. Tumors in domestic animals. 4.ed. Iowa State: University of California, 2002. p.788.

MITTAL, K.; DEMOPOULOS, R.I. MIB-1 (Ki-67), $\mathrm{p} 53$, receptor estrogen, and progesterone receptor expression in uterine smooth muscle tumors. Hum. Pathol., v.32, p.987-987, 2001.

REIN, M.S.; BARBIERI, R.L.; FRIEDMAN, A.J. Progesterone: a critical role in the pathogenesis of uterine myomas. Am. J. Obstet. Gynecol., v.172, p.1418, 1995.

RUBANYI, G.M.; JOHNS, A., KAUSER, K. Effect of estrogen on endothelial function and angiogenesis. Vasc. Pharmacol., v.38, p.89-98, 2002.

SEIBOLD, H.R.; WOLF, R.H. Neoplasms and proliferative lesions in 1065 nonhuman primate necropsies. Lab. Anim. Sci., v.23, p.533-539, 1973.

THOMSEN, L.L.; LAWTON, F.G.; KNOWLES, R.G. et al. Nitric oxide synthase in human gynecological cancer. Cancer Res., v.54, p.1352-1354, 1994.

TOFT, J.D.; MAC KENZIE, W.F. Endometrial stromal tumor in a chimpanzee. Vet. Pathol., v.12, p.32-36, 1975.

VU, K.; GREENSPAN, D.L.; WU, T.C. et al. Cellular proliferation, receptor estrogen, receptor progesterone, and bcl-2 expression in GnRH agonist-treated uterine leiomyomas. Hum. Pathol., v.29, p.359-363, 1998. 